\title{
○古川敦 ${ }^{1} \cdot$ 土井良平 ${ }^{1,2} \cdot$ 池本優真 $^{1} \cdot$ 内山雅史 ${ }^{1} \cdot$ 小芝未希子 ${ }^{1} \cdot$ \\ 前仲勝実 ${ }^{1} \cdot$ 佐藤美洋 ${ }^{1}$ \\ ( ${ }^{1}$ 北海道大学大学院薬学研究院 $\cdot{ }^{2}$ 大阪大学大学院工学研究科)
}

MicroED(micro Electron Diffraction)法はクライオ電子 顕微鏡を用いた構造決定法であり、近年着目されている 1。MicroED 法により、従来の X 線で構造決定が難しか つた $1 \mu \mathrm{m}$ 程度の結晶でも構造決定が可能である。一方 で、電子顕微鏡のステージの回転角度に制限があるため、 $1 つ の$ 結晶のデータセットでは構造決定が難しく、また、 結晶のグリッドへの吸着方向に偏りがあるため、複数の データセットを取る必要がある。今回、我々は、X 線構 造解析では構造決定することができかなかった Ni 錯体 の構造決定をMicroED 法で行なったので報告する。

加速電圧 $200 \mathrm{keV}$ のクライオ電子顕微鏡 Glacios (Thermo Fisher Scientific) を用いて測定を行なった。結 晶は主に数 $\mu \mathrm{m}$ のサズを測定に使用し、50 個以上の結 晶に電子線の照射し、データセットを得た（図 1 (a))。 得られたデータは DIALS で指数付けと積分を行ない、 KAMOを用いてデータセットのマージを行なった。
得られたデータを用いて、Olex2の SHELXT と SHELXL を用いて ab initio で構造決定を行い、図 $1(\mathrm{~b})$ の $\mathrm{Ni}$ 錯体 の構造決定に成功した ${ }^{2}$ 。当日は、サンプルの調製方法や 測定法、さらには解析方法を含めて議論したい。

1) Jones et al, ACS Central Science, 2018. 2)Doi R et al., Chem CatChem, 2021. (a)

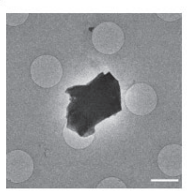

(b)

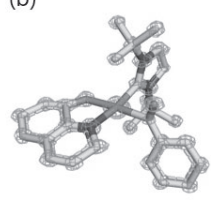

図 1. (a) グリッド上の結晶。スケールバーは $1 \mu \mathrm{m}$ を 示す。(b)MicroED によって明らかになった Ni 錯体の 構造。3 0 の $2 \mathrm{Fo}-\mathrm{Fc}$ マップを示す。緑、赤、青、マゼ ンダは炭素、酸素、窒素、ニッケル原子を表す。

\section{PB-I-02}

\author{
高圧 X線回折実験による \\ 高密度アモルファス水からの水 IV の結晶化その場観察
}

○小林 大輝, 小松一生, 鍵 裕之

（東大理）

水 IV は、氷の準安定相のひとつである。Salzmann ら は、氷 $\mathrm{I}_{\mathrm{h}}$ を $100 \mathrm{~K}$ 前後で加圧することで得られる高密度 アモルファス水 (HDA) を、 $0.8 \mathrm{GPa}$ 付近でゆっくりと加 熱することで、純粋な水 IV が得られると報告した[1]。 加えて、ラマンスペクトルから、彼らは水 IV が水素無秩 序相であると結論づけている[2]。しかし、これらの先行 研究は液体窒素温度で常圧に回収された試料で行われ たものであり、氷 IV の高圧その場観察が行われた例は ない。また、実際に水 IV が水素無秩序相であるか、中性 子回折による明確な証拠もいまだ得られていない。

我々は、ダイヤモンドアンビルセルを用いて Salzmann らの追実験を行った(先行研究[1][2]ではピストンシリン ダー型の高圧セルが用いられていた)。しかし、水 III や 水 XII の混在した水 IV が得られることが多く、既報の ように純粋な水 IV を再現性よく得ることは難しかった。 また、結晶化温度も既報と比較して高かった。
本発表では、氷 IV の結晶化条件と X 線回折を中心と したその場観察に関して、現時点での知見を報告する。

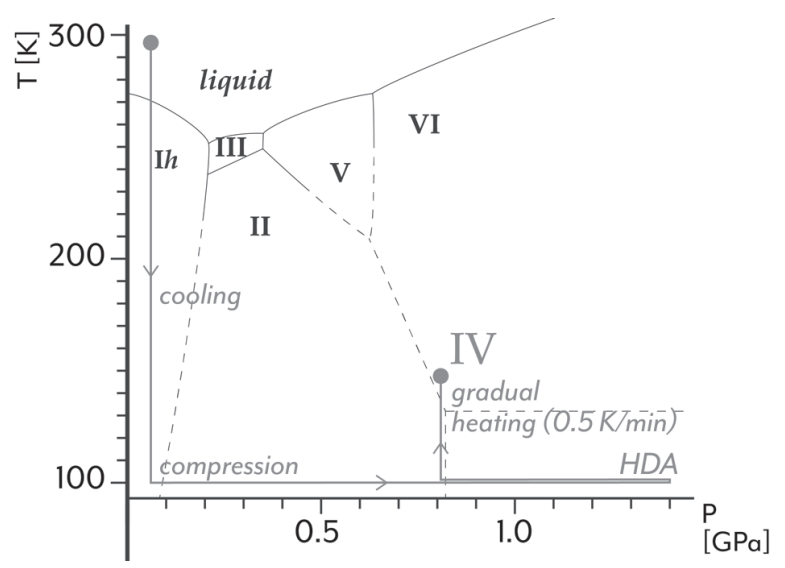

[1] Salzmann et al., J. Phys. Chem. B106, 22, 5587 (2002)

[2] Salzmann et al., J. Phys. Chem. B107, 12, 2807 (2003) 
光照射によって巨視的に変形する光駆動結晶は、遠 隔操作が可能であることから新しいアクチュエータ材 料として期待されている。アクチュエータ機能として 重要な指標である「力」は、結晶サイズが小さいとい う困難性からこれまでほとんど測定されてこなかった。 一方で、我々の既報研究で光駆動結晶から発生する力 （発生力）の測定系を確立し、作製した光駆動結晶の 発生力を実測した。回帰分析により発生力の実験条件 依存性を明らかにし、最適な結晶サイズ・光強度であ っても約 $8 \mathrm{mN}$ 程度しか出力できていないことを見出 した（図 1)。発生力はヤング率、結晶サイズ、変形の 仕方、光照射条件に依存するため、より大きい発生力 を達成するためには広い範囲で条件探索を行い、最適 な条件を見出す必要がある。そこで本研究では発生力 向上を最終的な目標とし、そのために機械学習を活用 して多様なヤング率を持つ光駆動結晶の設計と作製を 行った。
ヤング率を多様化させる方針を見出すために、過去 の論文から分子構造とヤング率を網羅的にまとめ、機 械学習に必要なデータセットを構築した。構築したデ ータセットに対して LASSO 回帰を行い、ヤング率の 大小に相関のある置換基を特定した。機械学習により 得られた分子設計指針をもとに複数の光反応性サリチ リデンアミン分子を合成し、結晶作製した。得られた 結晶の曲げ試験またはナノインデンテーションにより ヤング率を測定することで、機械学習による分子設計 の妥当性を検証した。

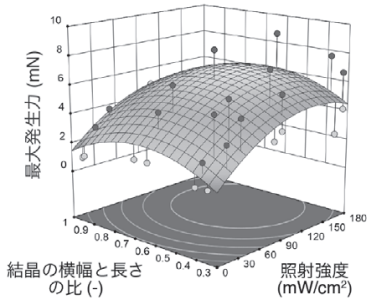

図 1. 光駆動結晶の発生力の三次元応答曲面

\section{PB-I-04}

\section{Synthesis of MOF nucleant with nanostructure via solution-phase self-assembly} Long $\mathrm{Li}^{1}$, Xiao-mei Sun ${ }^{2}$, Min $\mathrm{Yao}^{2}$

( ${ }^{1}$ Shenzhen Institutes of Advanced Technology, Chinese Academy of Sciences; ${ }^{2}$ Graduate School of Life Science, Hokkaido University)

Atomic structure of proteins provides key information for the deep understanding of the functional mechanism of proteins and succeeding in rational drug design. X-ray crystallography, a widely used technique to get the atomicresolution structures of proteins, depends on the availability of well-ordered single crystals. However, preparing protein crystals is a very difficult task that has long been a bottleneck to progress in solving the atomic structure of proteins, thus resulting impediments to modern biology.

To overcome the difficulty in producing well-ordered single crystals, heterologous substances called nucleants are used. It previously is demonstrated to facilitate crystal formation on its surfaces where crystal nucleation readily occurs. So far, various materials, including natural minerals, horse or human hair, molecularly imprinted polymers, etc., have been proposed. However, the field is still looking for new nucleants to make crystallization easier and costeffective.
Recently, we designed and constructed a series of metalorganic framework (MOF) with a regular structure for nucleants. A MOF nucleant was applied to 13 samples, including a membrane protein and hard-to-crystallize proteins. Among 11 successfully crystallized proteins, eight structures were solved, highlighting the potential of the MOF nucleant in crystallization. In addition, we proposed a nanostructure of the MOF to play a coupling role. Here, we report the nanostructure of the MOF and show a simple method for the feasible assembly of MOFs with the nanostructure (Fig). We will discuss the control strategy of the nanostructure formation in synthesis of $[\mathrm{Cu}(\mathrm{ett})] \mathrm{MOF}$. The relationship between protein crystallization and nanostructure will also be discussed.

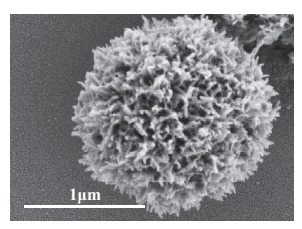

Fig. SEM image of $[\mathrm{Cu}(\mathrm{ett})]$ MOF with the nanostructure. 


\section{PB-I-05水和物結晶における湿度に依存した構造変化の追跡手法の検討 \\ ○小澤 和也 ${ }^{1}$ 、渡邊 真人 ${ }^{2}$ 、山村 滋典 ${ }^{1,2}$ ( ${ }^{1}$ 北里大院理、 ${ }^{2}$ 北里大理)}

\begin{abstract}
タンパク質などの水和物結晶は、一般的には乾燥によ り結晶水が失われると壊れてしまうが、水和・脱水和に 伴う構造変化が結晶性を保持したまま起こるものもあ る。従来の湿度制御下での X 線回折実験は、キャピラリ 一中で結晶を無機塩の飽和水溶液と共存させる方法が とられ連続的な湿度制御ができなかったが、我々は、湿 度を制御した気流を結晶に吹き付ける手法を開発する ことで連続的な湿度制御を可能とし、水和物結晶の水 和・脱水和による構造変化についての研究を行っている。 一方、高湿度で構造変化が起こる場合、結晶を結晶化母 液から取り出すと、空気と接触することで湿度制御前に 構造変化が起こることがあり問題となる。本発表では、 結晶の取り扱い法と、実際にタンパク質結晶に適用した 結果について報告する。

結晶の取り扱いについて、従来は粘性の低いオイルで くるみ X 線回折装置内の湿度制御気流下まで運んでい たが、その粘性の低さにより、結晶と空気との接触が原 因と考えられる結晶性の低下が見られる場合があった。
\end{abstract}

そこで、粘性の高いオイルを用いることで結晶の乾燥防 止に成功した。この手法により、リボヌクレアーゼ $\mathrm{A}$ 単 斜晶において、相対湿度 $(\mathrm{rh})$ が $90 \%$ 以上で見られる 3 つ の状態を明らかにした。また、リゾチーム正方晶におい て、結晶性を低湿度で低下させた後に高湿度に戻したと ころ、低湿度で長時間経過後では結晶性は回復しないが、 短時間では乾燥により低下した結晶性が回復する現象 が見られた(図 1)。

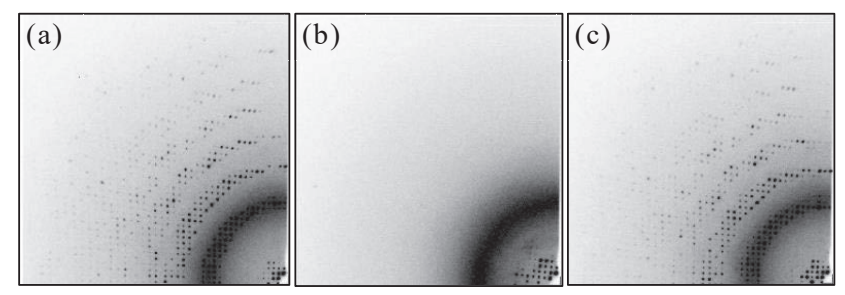

図 1 リゾチーム正方晶の振動写真の湿度変化 99\%rh(a)から 0\%rhに下げて 1 時間経過後(b)、再び $99 \%$ rh 八湿潤(c)。

\section{PB-I-06 X 線回折による $\mathrm{NH}_{4} \mathrm{Cl}$ の秩序一無秩序圧力誘起相転移の観察}

\section{○村上喬紀 ${ }^{1}$, 小松一生 ${ }^{1}$, 鍵裕之 ${ }^{1}$}

\section{( ${ }^{1}$ 東大院理)}

$\mathrm{NH}_{4} \mathrm{Cl}$ は、室温においては $\mathrm{CsCl}$ 型構造(空間群: $P m \overline{3} m$ ) の無秩序相 $\left(\beta\right.$ 相)であるが、 $-30{ }^{\circ} \mathrm{C}$ で空間群: $P \overline{4} 3 m$ の秩序 相 $(\delta$ 相 $)$ 一と転移する [1-2]。相転移温度は圧力とともに 上昇し、室温下でも約 $0.9 \mathrm{GPa}$ 以上で秩序相となる（図 1)。この圧力誘起相転移については、多くの先行研究が あるものの、意外にも X 線・中性子回折法による構造研 究例はほとんどない。そこで、本研究ではX 線回折を用 いて $\mathrm{NH}_{4} \mathrm{Cl}$ の圧力誘起相転移時の構造変化を捉えるこ とを目的とした。

試料である $\mathrm{NH}_{4} \mathrm{Cl}$ 粉末と状態方程式から圧力を算出 するための $\mathrm{NaCl}$ を圧媒体であるダフニーオイル (Daphne7575)とともにダイヤモンドアンビルセル(DAC) に封入した。本実験では、DACにとりつけたベローズを ヘリウムガス圧で膨らませることで一定の速度で加圧 しながら、イメージングプレート X 線回折装置(Rigaku, Micromax-007+R-axisIV $\left.{ }^{++}\right)$で連続的に X 線回折パターン を取得した。この連続的な加圧と測定により、非常に細
かい圧力ステップで X 線回折パターンを得ることが可 能になった。得られた X 線回折パターンを Rietveld 解析 することで、圧力の増加に伴う結晶構造の変化を観察し た。本ポスター発表では、上記の実験によって得られた 予察的な構造解析の結果を報告する。

[1] Yurtseven et al., Phys. Stat. Sol. (b) 244, 2589 (2007).

[2] Heyns, J. Phys. Chem. Sol., 41, 769 (1980).

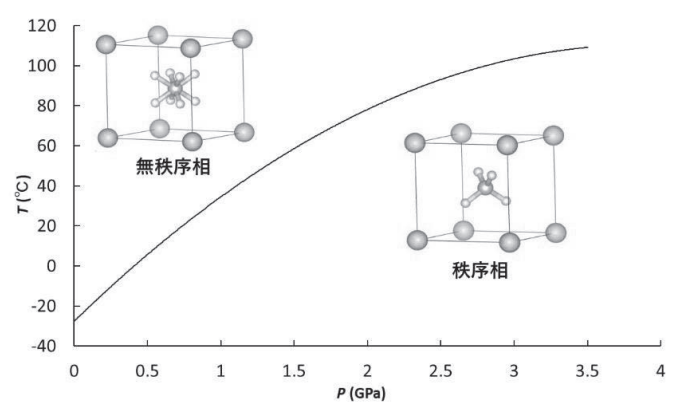

図 $1 \mathrm{NH}_{4} \mathrm{Cl}$ の相図と結晶構造(Yurtseven et al. [1]より加筆修正) 


\title{
PB-I-07
}

\author{
X 線異常散乱法を用いた AI 基近似結晶の精密構造解析
}

○牧野友紀、川又透、杉山和正 (東北大学大学院、東北大学金属材料研究所)

【緒言】六方晶と-A1-Cu-Cr は二十面体相と十角形相の分 解過程で出現するため、準結晶の構造を理解する上で重 要な鍵であると考えられている。本研究では、ら-A1-Cu$\mathrm{Cr}$ における正二十面体の中心元素の特定とクラスター の連結の解明を目的とする。

【実験方法】通常の X 線構造解析では区別が困難な $\mathrm{Cu}$ 元素と $\mathrm{Cr}$ 元素の分布を特定するため、高エネルギー加 速器研究機構において $\mathrm{Cu}$ 吸収端の低エネルギー $200 \mathrm{eV}$ の範囲におけるX 線異常散乱実験を行った。また、ら相 は $\mathrm{Al}_{80-65} \mathrm{Cu}_{5-20} \mathrm{Cr}_{15}$ の比較的広い範囲の化学組成で安定 であるため、 $\mathrm{Al}_{65} \mathrm{Cu}_{20} \mathrm{Cr}_{15}$ および $\mathrm{Al}_{72} \mathrm{Cu}_{16} \mathrm{Cr}_{12}$ の測定を行 うことで $\mathrm{Cu}$ 元素の役割の解明も行った。

【結果】一例として、 $\mathrm{Al}_{65} \mathrm{Cu}_{20} \mathrm{Cr}_{15}$ の構造モデルを右に示 寸 (図 1)。Cr 元素を中心とした正二十面体が存在し、互 いに陥入しながら連結していることが明らかとなった。 さらに、 $\mathrm{Al}_{65} \mathrm{Cu}_{20} \mathrm{Cr}_{15}$ でのみ出現した $\mathrm{Cu}$ 元素が正二十面 体配列の隙間に入り込む形で分布していることが確認
できた。このことから、一部の $\mathrm{Cu}$ 元素が侵入型固溶体 として存在し、正二十面体クラスターをつなぐ役割を担 っていることが判明した。

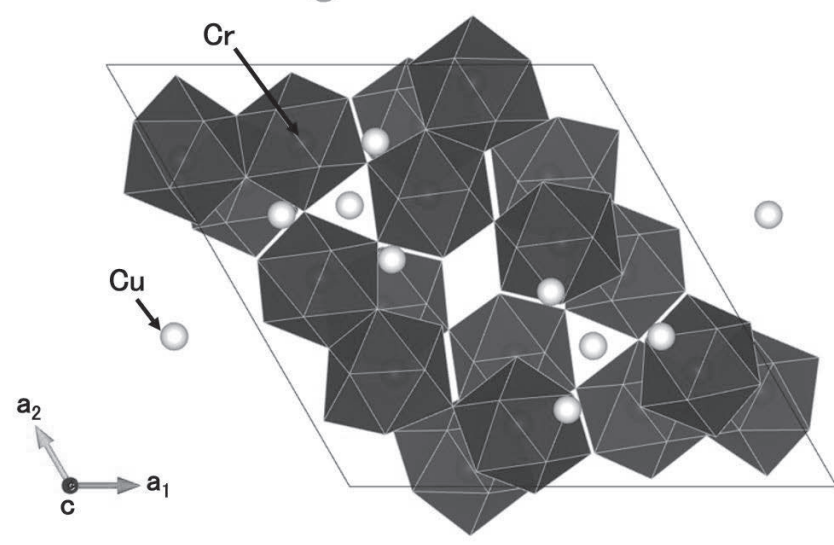

図1。正二十面体の連結によってあらわされる $\mathrm{Al}_{65} \mathrm{Cu}_{20} \mathrm{Cr}_{15}$ の構造モデル

\section{PB-I-08 本質的な酸素欠損カラムを持つ酸化物イオンープロトン混合伝導 体 $\mathrm{Ba}_{6} \mathrm{Ga}_{4} \mathrm{Y}_{2} \mathrm{O}_{15}$ の発見}

\section{○齊藤 馨 - 安井 雄太 - 村上 泰斗 - 藤井 孝太郎 - 八島 正知 ${ }^{*}$ (東京工業大学)}

【緒言】酸化物イオンおよびプロトン伝導体は燃料電 池などへの応用が可能な材料である。本研究では本質的 な酸素欠損カラムをもつ新構造型イオン伝導体 $\mathrm{Ba}_{6} \mathrm{Ga}_{4} \mathrm{Y}_{2} \mathrm{O}_{15}$ を発見し, 電気伝導度測定, 高温における結 晶構造の解析とイオン伝導経路の考察を行った。

【研究方法】固相反応法により $\mathrm{Ba}_{6} \mathrm{Ga}_{4} \mathrm{Y}_{2} \mathrm{O}_{15}$ を合成した。

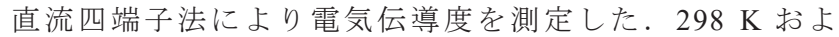
び $873 \mathrm{~K}$ で測定した中性子回折データのリートベルト解 析により結晶構造を明らかにし，Bond-valence based energy (BVE)計算を行いイオン拡散経路を調べた。

【結果と考察】1073 K 及び $1173 \mathrm{~K}$ において, $\mathrm{Ba}_{6} \mathrm{Ga}_{4} \mathrm{Y}_{2} \mathrm{O}_{15}$ の全電気伝導度は, 湿潤・乾燥雾囲気中で酸素分圧によ らず一定であり，イオン伝導が示唆された。乾燥・湿潤 雾囲気における全電気伝導度の比較から, $\mathrm{Ba}_{6} \mathrm{Ga}_{4} \mathrm{Y}_{2} \mathrm{O}_{15}$ が新構造型酸化物イオンープロトン混合伝導体である ことを明らかにした。 $\mathrm{Ba}_{6} \mathrm{Ga}_{4} \mathrm{Y}_{2} \mathrm{O}_{15}$ は $298 \mathrm{~K}$ および 873 $\mathrm{K}$ において空間群 $P 2 / c$ の $\mathrm{Ba}_{3} \mathrm{ErGa}_{2} \mathrm{O}_{7.5}$ 型構造として解析 に成功し，873 K においても本質的な酸素欠損 $\mathrm{BaO}_{1.5}$ 力
ラムを持つペロブスカイト関連酸化物であることを明 らかにした(図 a). BVE 計算から $b$ 軸に沿った $\mathrm{BaO}_{1.5}$ カ ラム内の-O2-O8-経路が最もエネルギー障壁の低い酸化 物イオン伝導経路であることがわかった(図 b). プロトン 伝導は, $\mathrm{BaO}_{1.5}$ カラムに $\mathrm{H}_{2} \mathrm{O}$ が入ることで起こると考え られ, $\mathrm{BaO}_{1.5}$ カラムがイオン伝導に重要であることを明 らかにした。
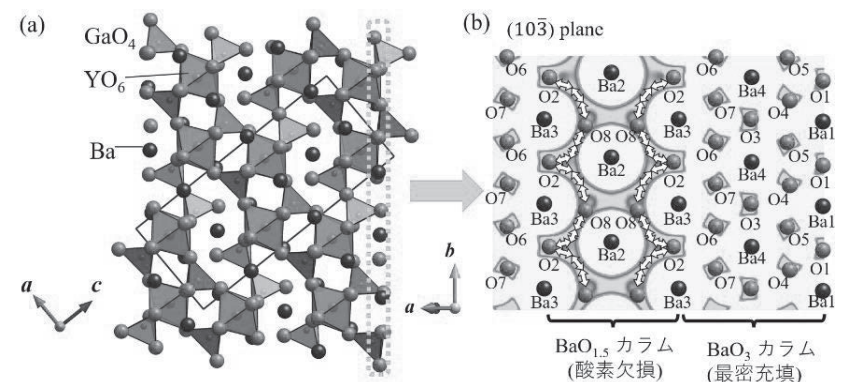

図. $873 \mathrm{~K}$ における $\mathrm{Ba}_{6} \mathrm{Ga}_{4} \mathrm{Y}_{2} \mathrm{O}_{15}$ の(a) 結晶構造と (b) $(10 \overline{3})$ 面における酸化物イオンの BVE 


\title{
PB-I-09
}

\section{○和田 雄貴、Usov Pavel、大津 博義、河野 正規}

(東京工業大学院)

ヘキサアザフェナレニルを基盤骨格とする配位子 4-TPHAP-を用いると同じ金属、同じ溶媒を用いても 種々の微量の添加剤を加えることにより全く異なった ネットワーク構造が速度論的に得られることが報告さ れている。1このように周辺の溶媒環境に強い影響を 受ける配位子からなるネットワーク錯体は、分子間相 互作用により細孔内の分子を配列する能力が高いと考 えられる。

このように細孔内にゲスト分子を配列させることで ネットワーク錯体の単結晶 X 線回折を測定することで ゲストの構造解析を行う手法である結晶スポンジ法は 結晶化を必要としない構造解析法として現在非常に注 目されている分野の一つである。2 その問題点の一つ として、この手法が適用可能であるホスト結晶の種類 の少なさが上げられる。

本研究ではヘキサアザフェナレニル骨格と細孔内の 分子の分子間相互作用性を最大限高めるためにネット
ワーク構造合成後、回転しない置換基である3-ピリジ ル基を有している 3-TPHAP-を含むネットワーク錯体 を用いてゲスト包接、構造解析を行った。まずは種々 のゲストの包接を行いホストとの相互作用を確認した。 その後、医薬品成分の包接を行いゲストの構造解析を 行った。

[参考文献]

1. T. Kojima, T. Yamada, Y. Yakiyama, E. Ishikawa, Y. Morita, M. Ebihara, M. Kawano, CrystEngComm, 2014, 16,6335 .

2. Y. Inokuma, S. Yoshioka, J. Ariyoshi, T. Arai, Y. Hitora, K. Takada, S. Matsunaga, K. Rissanen, M. Fujita, Nature, 2013, 495, 461-466.

\section{PB-I-10 孤立空間を利用した選択的な $\mathrm{CO}_{2}$ 貯蔵能を有するネットワーク錯体}

\author{
○嶋田 光将 ${ }^{1}$ 、Pavel Usov ${ }^{1}$ 、和田 雄貴 ${ }^{1}$ 、 \\ 大津 博義 ${ }^{1}$ 、渡邊 卓 ${ }^{2}$ 、松本 隆也 ${ }^{1,2}$ 、河野 正規 ${ }^{1}$ \\ ( ${ }^{1}$ 東工大院理、 ${ }^{2} \operatorname{ENEOS}($ 株))
}

有機多座配位子と金属イオンで構成される細孔性ネ ットワーク錯体 $(\mathrm{PCN})$ は、その設計可能性の高さから有 力な二酸化炭素吸着材として注目を集めている。

本研究では四面体型の配位構造を持つ ${ }^{[1]}$ 新規ピリミジ ン配位子とヨウ化銅(I)を組み合わせることでキュバン 型ヨウ化銅クラスターをコネクターとした、孤立空間を 有するネットワーク錯体を合成した。

室温での吸着等温線および IR スペクトルの測定によ り、このネットワークが常圧で $\mathrm{CO}_{2}$ を選択的に吸着し、 空気中に拈いて 1 週間以上 $\mathrm{CO}_{2}$ を保持することを確認し た。加えて、 $\mathrm{CO}_{2}$ 雾囲気下に 1 日間封入した単結晶に対 する $\mathrm{X}$ 線構造解析によって、孤立空間内に包接された $\mathrm{CO}_{2}$ を観測することに成功し、 $\mathrm{CO}_{2}$ とネットワークの間 に分散力以上の相互作用が働かないことが示唆された。 また、吸着の前後でネットワークの構造に大きな変化が 見られず、その保持能力、再生可能性の高さから $\mathrm{CO}_{2}$ 貯
蔵材としての活用が期待される。

さらに、汎用原子シミュレーター「Matlantis（マトラ ンティス)」を用いた $\mathrm{CO}_{2}$ の吸着エネルギーおよびネッ トワーク中の $\mathrm{CO}_{2}$ の拡散経路の計算により、吸着メカニ ズムを解明し、 $\mathrm{CO}_{2}$ 吸着材の新規な設計戦略が示された。 (a)

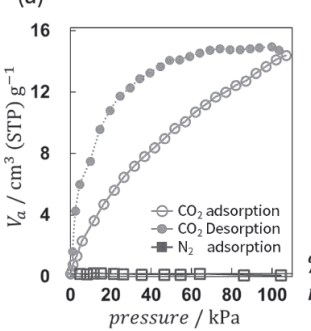

(b)

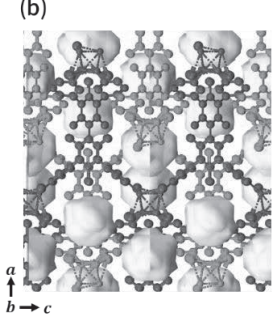

(c)

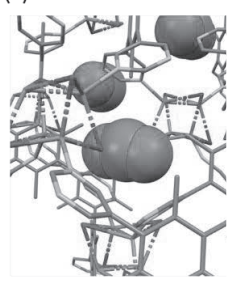

Figure (a) $298 \mathrm{~K}$ におけるネットワークの $\mathrm{CO}_{2}$ と $\mathrm{N}_{2}$ の吸 着等温線 (b)単結晶 $\mathrm{X}$ 線構造解析によるネットワークの 構造と孤立空間 (c)孤立空間中に捕捉された $\mathrm{CO}_{2}$

[1] Zhong Li et al, ACS Sustainable Chem. Eng. 8, 41, 15378-15404 (2020). 


\section{PB-I-11}

\section{多孔性配位高分子のガス吸着過程における格子変化と速度論}

\section{○芦谷 拓嵩 ${ }^{1}$ 、河口 彰吾 ${ }^{2}$ 、石橋 広記 ${ }^{1}$ 、 \\ 大竹 研一 ${ }^{3}$ 、北川 進 ${ }^{3}$ 、久保田 佳基}

(阪府大院理 ${ }^{1} 、$ JASRI/SPring $-8^{2}$ 、京都大学 $/$ iCeMS $^{3}$ )

多孔性配位高分子（PCP）がガス吸着の過程でどの ようにガス分子を認識するのかは大変興味深いが、特 にガス吸着初期過程の dynamic な構造について直接的 に調べられた例はほとんどない。このような構造情報 の取得は、ガス分子と細孔表面との相互作用の始まり、 また細孔内への拡散に関する知見を与え、ガス吸着過 程全体の理解に繋がると期待される。

dynamic な構造情報は、吸着等温測定など従来の測 定手法では引き出すことが難しい。このような情報を 直接的に引き出す心゙く、SPring-8の BL02B2 において ガス導入システムを用いた時間分解粉末回折実験を行 った。システム内に貯めた一定量のガスをサンプルに 即座に導入し、この操作と連動して 1 秒露光の回折デ ータ測定を繰り返した（gas-shot）。CPL-1 において、 degas 状態から $32 \mathrm{kPa} の \mathrm{CO}_{2}$ ガスを導入してから 80 秒 後までの回折パターンの変化を図 1 に示寸。得られた
回折データ毎に全回折パターンの LeBail フィッティ ングを行った。結果、結晶格子の変化の速さは各軸で 少し異なることが分かった。さらに、特定の回折ピー クの強度変化から Kolmogorov-Johnson-Mehl-Avrami （KJMA）理論を用 いて圧力や温度によ る吸着速度の依存性 について調べた。発 表では、細孔の大き さの異なる $\mathrm{PCP} と$ 比 較しながら、 degas 相から吸着相への移 り変わりについて、 その性質と吸着メカ ニズムについて議論 する。

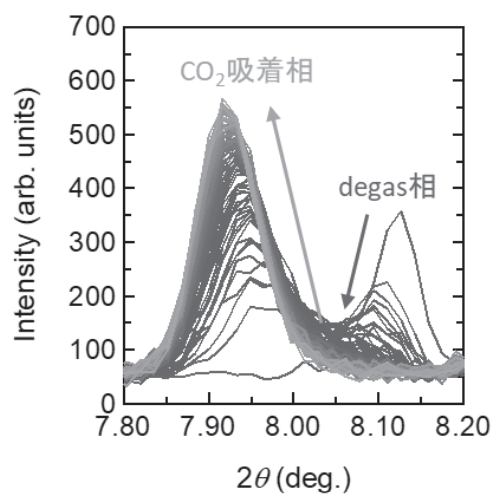

図 1 CPL-1の $195 \mathrm{~K}$ における $\mathrm{CO}_{2}$ 導入時の回折パターン

\section{PB-I-12 \\ Ir 錯体とレゾルシンアレーンからなる細孔性結晶の合成と性質 \\ ○小倉 祥太、堀内 新之介、作田 絵里、有川康弘、馬越啓介 (長崎大学大学院、工学研究科)}

金属イオンと有機配位子の可逆な配位結合により形 成される MOF, PCP などの多孔質結晶は，近年材料研 究が盛んに行われている。本研究ではカチオン性 Ir 錯 体とレゾルシンアレーンの分子間相互作用によって細 孔性結晶が得られることを確認し, その結晶構造解析 と性質解明を行った。

エタノール-水混合溶媒中で $\operatorname{Ir}$ 錯体（黄色固体）と レゾルシンアレーン（白色固体）の結晶化を行ったと ころ，時間の経過とともにそれらの複合体からなる茶 色板状結晶が析出した。単結晶 $\mathrm{X}$ 線構造解析により, 錯イオン，レゾルシンアレーン，塩化物イオンが 1:1:0.5の割合で含まれていることが分かった。レゾル シンアレーンの一部が脱プロトン化し, 有機アニオン として存在していることが示唆される。これは結晶色 が茶色に呈色しており電荷移動に帰属される新たな可 視光吸収帯が観測されたことからも支持される.

得られた結晶は 1 次元細孔（約 $1 \mathrm{~nm} \times 1 \mathrm{~nm}$ )を形成
していることを確認した（図1）。そこでこの結晶を純 水に $24 \mathrm{~h}$ 浸漬し, 結晶構造解析を行ったところ, 単結 晶性を維持したまま細孔内の溶媒分子を交換できるこ とが分かった。合成直後の結晶では, 細孔壁面にエタ ノール分子が観測された一方で，純水に浸漬した結晶 ではエタノール分子は見えなくなり，水分子が細孔壁 面でクラスター構造を形成している様子が観測された。
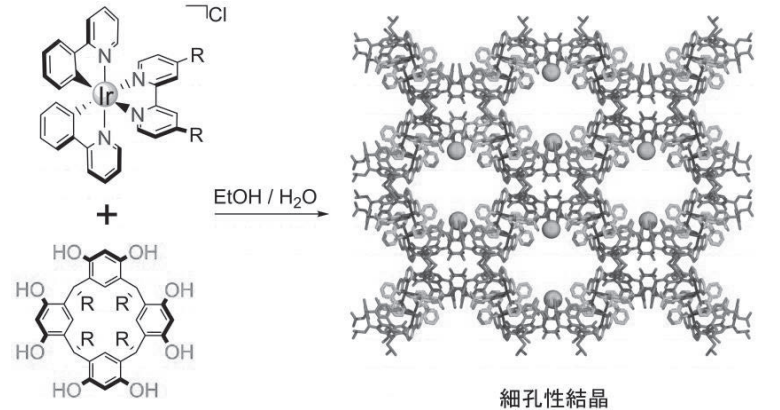

図 1. 細孔性結晶の合成方法とその結晶構造. 


\section{○井上 晴貴 ${ }^{1}$ 、小澤 芳樹 ${ }^{1}$ 、田原 圭志朗 ${ }^{1}$ 、小野利和 ${ }^{2}$ 、阿部 正明 ${ }^{1}$ \\ $\left({ }^{1}\right.$ 兵庫県立大院理、 ${ }^{2}$ 九大院エ)}

【緒言】近年、環境応答型の機能性材料が注目を集め ている。外部刺激に応じて物質の発光挙動が可逆的に 変化する現象は、環境の変化を目に見える形で認識で きることからセンサー材料への応用が期待されている。 今回、我々は結晶溶媒分子の脱着で発光強度が大幅に 変化する $\mathrm{Cu}(\mathrm{I})$ および $\mathrm{Ag}(\mathrm{I})$ 六核錯体結晶を報告する。

【実験】2-メルカプトニコチン酸 $\left(\mathrm{H}_{2} \mathrm{mna}\right)$ に酢酸銅 $(\mathrm{I})$ または酸化銀 $(\mathrm{I})$ を反応させることにより、paddlewheel 型 $\mathrm{Cu}(\mathrm{I})$ および $\mathrm{Ag}(\mathrm{I})$ 中性六核錯体 $\left[\mathrm{M}_{6}(\mathrm{Hmna})_{6}\right](\mathrm{M}=$ $\mathrm{Cu}$ (1)、Ag（2)を合成し、 $N, N$ ’’ジメチルホルムアミド (DMF)あるいはジメチルスルホキシド(DMSO)を用い た再結晶により溶媒和結晶 $\mathbf{1} \cdot 7 \mathrm{DMF}$ および 2 -8DMSO を得た。これら結晶について単結晶 $\mathrm{X}$ 線構造解析を行 い、真空乾燥と溶媒蒸気曝露による溶媒分子の吸脱着 挙動を固体発光スペクトルの測定により追跡した。

【結果と考察】図 1(a)に銀錯体 2 の分子構造、(b)にパ ッキング図を示す。DMSO 分子が錯体 2 の外側に突き

出したカルボキシル基へ水素結合によってトラップさ れ、錯体分子と溶媒分子の 2 次元層が交互に積み重な る構造を取る。2.8DMSO はUV照射により強い黄緑色 発光 $\left(\lambda_{\mathrm{em}}=545 \mathrm{~nm}\right)$ を示すが加熱真空下では溶媒脱離 が起こり発光強度が大幅に低下寸る。無溶媒和の 2 を DMSO 蒸気に晒すと、溶媒が取り込まれることで発光 強度が回復する。1·7DMF も DMF 蒸気に対し同様の現 象を示した。溶媒和結晶の発光寿命は脱溶媒のものに 比べ大幅に増大寸ることから、溶媒和結晶では錯体と 溶媒との水素結合により錯体が溶媒分子に囲まれるこ とで無輻射失活が抑制され強発光を示すと推定される。

(a)

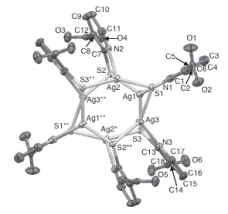

図 1. (a) $\left[\mathrm{Ag}_{6}(\mathrm{Hmna})_{6}\right]$ の分子構造 8DMSOの結晶パッキング図 (b)

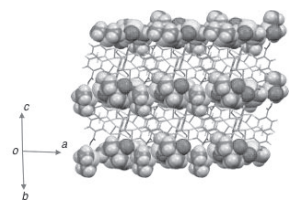

(b) $\left[\mathrm{Ag}_{6}(\mathrm{Hmna})_{6}\right]$

\section{PB-I-14}

リン光性レニゥム (I) 錯体結晶のゲスト誘起次元クロスオーバー現象 :

揮発性有機溶媒に感応した発光強度増大

○松田雄貴 ${ }^{1}$ 、小澤芳樹 ${ }^{1}$ 、田原圭志朗 ${ }^{1}$ 、小野利和 ${ }^{2}$ 、杉本邦久 ${ }^{3}$ 、小林慎太郎 ${ }^{3}$ 、

河口彰吾 ${ }^{3}$ 、阿部正明 ${ }^{1}$ ( ${ }^{1}$ 兵庫県立大院理、 ${ }^{2}$ 九大院工、 ${ }^{3}$ JASRI/SPring-8)

近年、環境污染問題の原因の一つである揮発性有機 溶媒(Volatile Organic Compound; VOC)を鋭敏に検知す ることが重要視されており、そうした機能を有する発 光性ベイポクロミック錯体の開発が期待されている。 本研究では、ピリジルチアゾール骨格を有し室温リン 光を示すトリカルボニルレニウム (I)錯体 1 の固体発光 ベイポクロミズム特性を検討した。その結果、VOCの 選択的吸蔵に伴うリン光強度の増大化、及びゲスト溶 媒包接化に伴う結晶構造変化が鍵となる興味深い現象 が見出された。錯体 $\mathbf{1}$ を異なる溶媒の組み合わせによ り再結晶化したところ、溶媒分子を包接しない無溶媒 結晶 $\mathbf{1} 2$ と 6 種の溶媒包接結晶 $\mathbf{1} \cdot \boldsymbol{n} \operatorname{Sol}(n=1,2)$ が単離 された。結晶中において、対向した 2 つの錯体分子が 2 本の $\mathrm{C}-\mathrm{H} \cdots \mathrm{O}$ 水素結合により支持されたダイマー12、 及びそれらが 2 本の弱い $\mathrm{Br}$ ‥S シ ショートコンタクト により連結した 1 次元鎖が生成していた。無溶媒結晶 ではその 1 次元鎖が奥行き方向にさらなる $\mathrm{C}-\mathrm{H} \cdots \mathrm{O}$ 水
素結合により連結した 2 次元シートを形成しており、 ゲス卜溶媒の導入に伴い横方向への 2 次元シートに変 化する $\{2 \mathrm{D} \rightleftarrows 2 \mathrm{D}\}$ シート転換、及び 3 次元構造に変化 する $\{2 \mathrm{D} \rightleftarrows 3 \mathrm{D}\}$ 次元クロスオーバーが観測された。固 体発光ベイポクロミズムの検討では試料として $\mathbf{1 2}$ ・ $\mathrm{CHCl}_{3}$ をメノウ乳鉢ですりつぶし真空乾燥 $\left(120^{\circ} \mathrm{C}, 3 \mathrm{~h}\right)$ することで $\mathrm{CHCl}_{3}$ 分子が完全に脱離した脱溶媒化結晶 12 を用い、固体発光スペクトル測定により無溶媒結晶 12 との一致が確認された。 $\mathrm{CHCl}_{3}$ 雾囲気において脱溶 媒化結晶の固体発光特性と PXRDの回折パターンが変 化し、各々が $\mathbf{1}_{2}$ ・ $\mathrm{CHCl}_{3}$ に一致した ことにより、図 1 に示すような可逆 的なゲスト吸脱着 $\left(1_{2} \rightleftarrows 1_{2} \cdot \mathrm{CHCl}_{3}\right)$

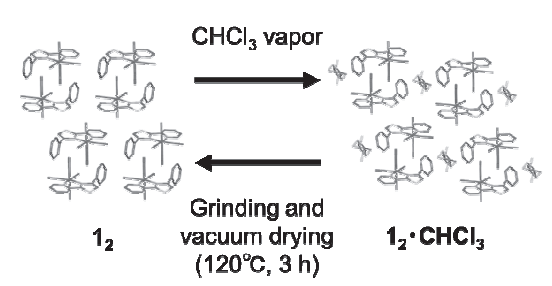

が見出された。図 1 . 可逆的な $\mathrm{CHCl}_{3}$ 分子吸脱着挙動. 


\title{
PB-I-15
}

\author{
ヨウ素架橋銅 $(\mathrm{I})$ 二核及び四核錯体の \\ 結晶相及びアモルファス相における発光ピエゾクロミズム \\ ○宮下 花、小澤 芳樹、田原圭志朗、阿部 正明 \\ （兵庫県立大院理）
}

発光性多核銅 $(\mathrm{I})$ 錯体には、温度や圧力変化により発光 挙動が変化する外部刺激応答性を持つものが多い[1]。本 研究ではキュバン型四核(1)、ヨウ素架橋二核(2)錯体を研 究対象とした。発光の起源は主に $\mathrm{Cu} の 4 \mathrm{~s}, 4 \mathrm{p}$ 軌道が寄 与するクラスターセンター $\left({ }^{3} \mathrm{CC}\right)$ 励起状態であり、 $\mathrm{Cu} \cdots \mathrm{Cu}$ 距離の短縮を伴う構造緩和が起こるとされる ${ }^{[2]}$ 。 圧力に応じて発光色が変化する発光ピエゾクロミズム 現象はこれまで結晶相での研究がほとんどで、アモルフ アス相との比較例はない。今回我々は結晶相及びアモル ファス相での発光ピエゾクロミズムについて報告する。 UV 照射下での試料の発光スペクトルを図1(a)に示す。 錯体 1、2 の結晶状態での発光極大波長は常温常圧でそ れぞれ 506、465 nm であり、すり潰してアモルファス状 態にした 1G、2Gではそれぞれ 556、546 nm に長波長シ フトした。発光極大の圧力依存性を図 1(b)に示す。圧力 を印加すると 1 では加圧直後から発光スペクトルのシフ トが見られるのに対して、アモルファス相(1G)では加圧
直後は発光色が変化せず $4 \mathrm{GPa}$ より高圧になると発光色 が変化し始めた。結晶相では加圧に伴い構造緩和が抑制 されたまま分子が変形することで発光に変化が現れる。 一方アモルファス相では、構造緩和の抑制は極めて小さ いために低圧領域では圧力効果が見られないが、より高 圧領域で、構造緩和が起きた時以上の $\mathrm{Cu} \cdots \mathrm{Cu}$ 短縮を伴 う分子変形が起き、発光に影響が出ていると考えられる。
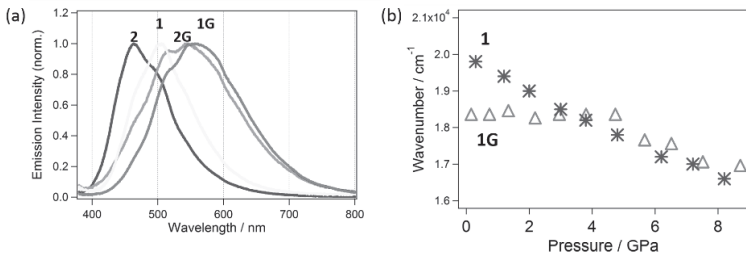

図1.a 室温での発光スペクトル。 $\mathrm{b}$ 発光極大エネル ギーの圧力依存性。

1) S. Nagaoka, M. Abe, et al., Chem. Lett., 2018, 47, 11011104.

2) P. C. Ford, et al., Chem. Rev., 1999, 99, 3625-3657.

\section{PB-I-16} で特異的な相互作用を形成 し、物性の発現機序に関与寸 ることが知られている。本研 究室ではこれまで精神安定 剤の原料として利用されるフ エノチアジンと類似した骨格 を持つ多環状分子(図 1) に着 目してきた。この分子は分子

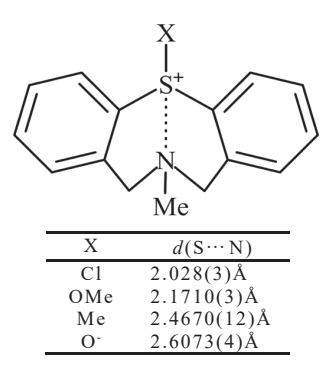

図 1 ジベンゾチアゾシン誘導体
渡環型分子内 $\mathrm{S} \cdots \mathrm{N}$ 相互作用の電子密度分布解析 ージベンゾチアゾシン S-OMe 誘導体—

○北拓真 · 安井 正憲

（電通大院情報理工）

内 $\mathrm{S} \cdots \mathrm{N}$ 相互作用を有し、 $\mathrm{S}$ 上置換基の電子求引性によ って $\mathrm{S} \cdots \mathrm{N}$ 間距離が変化する。本研究では置換基が $\mathrm{OMe}$ 基の誘導体に関して、構造解析・電子密度分布解析を行 い、置換基による相互作用の変化を定量的に比較・評価 する。これまでに OMe 基の合成・結晶化を行い、MoKa 線源、 $100 \mathrm{~K}$ 条件下の $\mathrm{X}$ 線回折実験で得られた $2 \theta \leq 106.2^{\circ}$ の反射を用いて通常解析、また、 $2 \theta \geq 52.3^{\circ}$ の反射を用い て高角解析を行った。多極子展開最小二乗法による精密
化を行い得られた $\mathrm{R}$ 值を表 1 に記す。 $\mathrm{O} 、 \mathrm{~S} 、 \mathrm{~N}$ 原子を含 む平面上の残差マップ上(図 2)に大きなピークは見られ ず、良好な $\mathrm{R}$ 值が得られた。図 3 は同一平面上の model deformation map である。 $\mathrm{N}$ の孤立電子は電子不足の $\mathrm{S}$ の 方向に向かっていることが分かる。現在、トポロジカル 解析によって $\mathrm{S} \cdots \mathrm{N}$ 間の Bond Path や、BCPにおける電 子密度、Laplacian $\left(\nabla^{2} \rho\right)$ を求め、 $\mathrm{S} \cdots \mathrm{N}$ 相互作用がどのよ うな電子的相互作用であるのか定量的に評価し、置換基 による相互作用の変化を検討している。

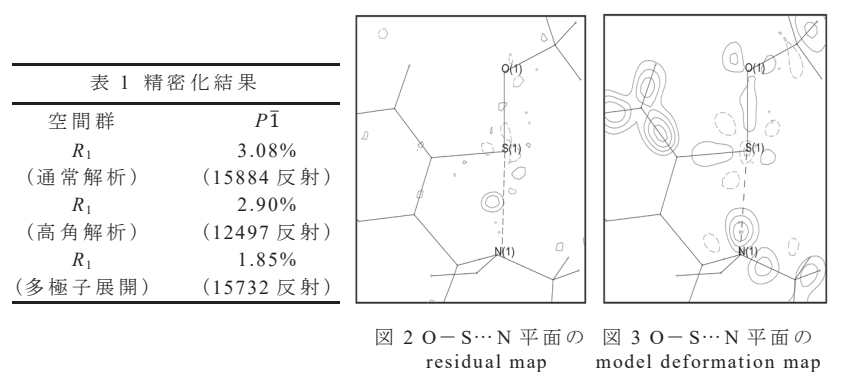




\section{O大嶋 紬 ${ }^{1}$ 、藤戸 貴之 ${ }^{1}$ 、植田 圭祐 ${ }^{1}$ 、 東 顕二郎 ${ }^{1}$ 、桝 飛雄真 ${ }^{2}$ 、森部 久仁一 \\ $\left({ }^{1}\right.$ 千葉大学大学院薬学研究院、 ${ }^{2}$ 千葉大学共用機器センター)}

【目的】薬物の物性改善手法として塩共結晶化が検討さ れている。本研究では、ロキソプロフェンナトリウム $(\mathrm{LOXNa})$ の吸湿性改善を目的として、コフォーマーとし て糖類を用いた塩共結晶を調製し、吸湿性と結晶構造の 関係性を考察した。

【実験】 $\mathrm{LOXNa} \cdot 2 \mathrm{H}_{2} \mathrm{O}$ とフルクトース (FRU)及びリボー ス (RIB)をそれぞれモル比 $1: 1$ で混合し、振動型粉砕機 で粉砕することで試料を得た。また、各塩共結晶につい て、溶媒蒸発法による単結晶調製を行った。

【結果・考察】水蒸気吸脱着測定の結果、LOXNaは 2 水 和物を形成した一方、LOXNa-FRU 及びLOXNa-RIB 塩共 結晶はそれぞれ、無水物及び 1 水和物を形成し、塩共結 晶化によるLOXNaの吸湿性低下が示された。単結晶 X 線構造解析の結果、いずれの塩共結晶中でも $\mathrm{Na}^{+}$と LOX
分子のカルボン酸間のイオン結合は認められず、 $\mathrm{Na}^{+}$は 糖類 3 分子と配位結合することで、一次元連鎖構造を形 成した(Fig. 1)。糖類が $\mathrm{Na}^{+}$を取り囲む構造を形成するこ とで、水分子の $\mathrm{Na}^{+}$への配位が阻害され、LOXNa の吸湿 性が低下したと推察した。また、RIBより水酸基を一つ 多く有するFRU は、FRU の水酸基のみで強固な水素結 合ネットワー クを形成し た。その結果、 LOXNa-FRU 塩共結晶が安 定な無水物を 形成したと推 察した。

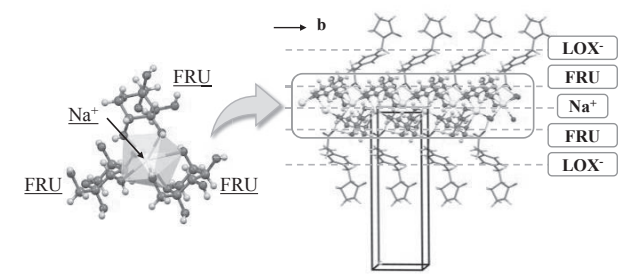

Fig. 1. 1D chain structure along $b$-axis of LOXNa-FRU salt cocrystal.

\section{PB-I-18}

\section{医薬品原薬カルベジロール塩の結晶化メカニズム理解}

\section{○内海 洋平、貫井勇吾、川嶋 裕介、古石誉之、福澤薰、米持 悦生 （星薬大）}

カルベジロール（CVD）（図 1 ) は構造中に第二級アミンを 有することから、コフォーマー にカルボン酸を用いた塩並び に非晶質複合体を形成する。非

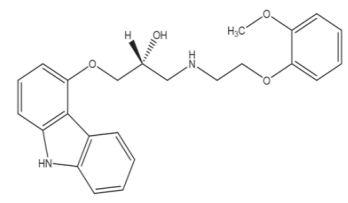

図 1,カルベジロール (CVD) 晶質は物理的・化学的に結晶よりも不安定であることか ら、より安定性の高い結晶を晶析させるメカニズムの理 解は重要である。本研究では、CVDとジカルボン酸を用 いた結晶構造と安定化メカニズムの解明を試みた。

炭素数 2 から 10 までの直鎖状ジカルボン酸とベン ゼン環を有するフタル酸（FA）、イソフタル酸（IA）、テ レフタル酸（TA）をコフォーマーとして多種の溶媒を用 いスクリーニングを行った。結果、炭素数 2 から 6 まで の直鎖状ジカルボン酸と FA、TAでは、PXRD 及び単結 晶 $\mathrm{X}$ 線構造解析により複合体形成が確認された。炭素数 7 から 10 までの直鎖状ジカルボン酸とIA においては 非晶質となることがわかった。
再結晶により晶析した結晶を構造解析したところ、ア ジピン酸との塩では、空間群が P-1 である 1 種類の無溶 媒和物と 4 種類の溶媒和物が得られた。無溶媒和物は、 隣接する CVD のメトキシ基とカルバゾール基が $\mathrm{CH}-\pi$ 、 $\pi-\pi$ 相互作用し安定化することで、結晶化に繋がったこ とが示唆された。溶媒和物においては、再結晶溶媒が主 に図 2 の位置を占めていることが分かった。炭素数が 4 や 5 の直鎖状ジカルボン酸および FA,TAにおいても同様 の空間配置をした結晶構造が得られた。したがって、図 2 の位置で CVD と溶媒が水素結合を形成することによ り、フレキシブルな CVD のコンフォメーションが定ま ることが結晶化の要因であると強く示唆された。
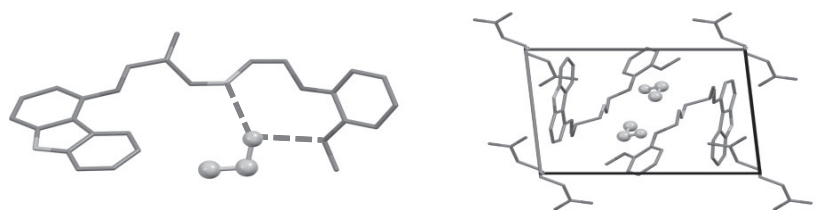

図 2, CVD とエタノールとの水素結合（左）およびパッキング構造（右） 


\title{
PB-I-19
}

カルバマゼピン共結晶の各結晶面における溶媒媒介相転移

\author{
○大森 まあや・菅野 清彦 \\ (立命館大学大学院 薬学研究科)
}

【緒言】共結晶は, 新薬候補化合物の水溶性や安定性, 製造 性を改善する技術として注目されている。しかし, 水溶液中で の安定形結晶への速やかな溶媒媒介相転移により, 水溶性改善 効果が認められない場合がある. ${ }^{1}$ 本研究の目的は, 共結晶粒子 表面における安定形結晶への溶媒媒介相転移に対して, 各結晶 面が与える影響を解明することである。

【方法】モデル共結晶として, カルバマゼピンーサッカリン共 結晶(CBZ-SAC)を用いた。溶媒蒸発法により, $5 \mathrm{~mm}$ 程の巨視的 な単結晶を作成した(図a)。単結晶の各結晶面を, X 線回折測定 を用いたミラー指数付けにより, 同定した. 各結晶面を, pH 6.5 リン酸緩衝液に 30 秒間浸漬後, 電子顕微鏡観察した。また, 各 結晶面に $\mathrm{pH}$ ６.5 リン酸緩衝液を $1 \mu \mathrm{L}$ 滴下し, 各結晶面での溶 媒媒介相転移を, リアルタイムで偏光顕微鏡観察した。さらに, 各結晶面に析出した結晶を, 顕微ラマン分光法により同定した. 【結果・考察】電子顕微鏡観察より, (010)面では, 安定形結 晶が, 結晶面全体を覆うように瞬時に析出し, 広範囲での速や かな溶媒媒介相転移が起こった。一方，(001）面および(100)
面では, 安定形結晶は傷やエッジ部分のみから析出し, 滑らか な部分からは析出しなかった。また, リアルタイム観察により, (010), (101)および(111) 面では, 安定形結晶の析出が, 結晶 面全体で 10 秒以内に起こった。一方，(001), (100)および (110)面では, 安定形結晶は傷やエッジ部分のみから析出し, 滑らかな部分からは析出しなかった. 以上より, 各結晶面にお いて, 共結晶の溶媒媒介相転移の速度, 範囲および起点は異な った。原因として, 結晶面間での, 過飽和度, 疎水性およびエ ピタキシャル成長の違いが考えられた。

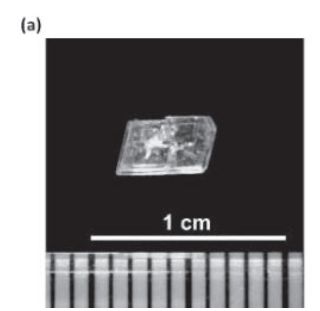

(b)

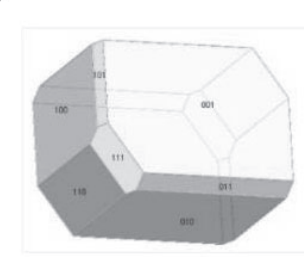

図 (a) CBZ-SACの単結晶（b)BFDH 法により予測された結晶形 [1] Omori M, Sugano K et al., Mol. Pharmaceutics., 17 (10), (2020)

\section{PB-I-20}

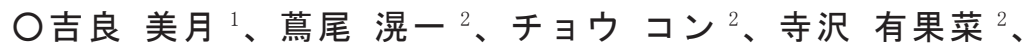 佐藤 宗太 ${ }^{3}$ 、吉田 知史 ${ }^{3}$ 、柴田 哲男 ${ }^{4}$ 、朝日透 ${ }^{1}$ \\ ( ${ }^{1}$ 早大先進理工、 ${ }^{2}$ 早大院先進理工、 ${ }^{3}$ 東大院工、 ${ }^{4}$ 名エ大院エ)}

1958 年に鎮静催眠剂として開発されたサリドマイ ド（TD）は、催奇形性を引き起こす副作用が報告され、 販売が停止された。その後、Blaschke らは(S)-TD が催 奇形性の原因であることを報告し(Blaschke, G et al., F. Arzneimittel-Forschung, 29, 1640-1642(1979))、この報告 の後、薬剂のキラリティーに関する研究の重要性が認 識されるようになった。一方，TD は水溶液中で容易 にラセミ化することが明らかとなった(Knoche, B et al., J. Chromatogr. A, 666, 235-240(1994)など)。これにより、 Blaschke の解勫の正否が議論され、TD の催奇形性の機 構解明は大いに関心を集めた。最近、TD のラセミ化 に関する重要な研究結果が報告され(Tokunaga, E et al., Sci.Rep., 8, 17131(2018))、Blaschkeの報告を裏付ける ものとなっている。一方、溶液状態に比へ、結晶状態 の TD の諸性質は十分に解明されているとは言えない。 そこで、我々は単結晶状態の TD の光学的性質及び外
部環境変化によるそれらの変化を明らかにし、結晶状 態でのラセミ化を調べる研究に着手することとした。

まず、良質な単結晶を育成できる条件を見出すため に試行を重ねた結果、昇華法を用いて良質な薄片単結 晶が得られることを見出した。X線結晶構造解析によ り、昇華法で育成された結晶が溶媒蒸発法で育成され た結晶と同じ構造であることが確認できた(T. Suzuki, et al., Phase Transitions, 83, 223 (2010)) 。さらに、キラ ル異方性物質の直線複屈折 (linear birefringence; LB)、 直線二色性 (linear dichroism; LD)、円複屈折 (circular birefringence; $\mathrm{CB}$ )、円二色性(circular dichroism; CD)を 同時測定できる Generalized High Accuracy Universal Polarimeter(G-HAUP、例えば、Nakagawa, K., Asahi, T., Sci. Rep., 9，18453 (2019))を用いて、TDの LB、LD、 $\mathrm{CB} 、 \mathrm{CD}$ の波長依存性を測定し、他の手法では得るこ とのできない興味深い結果を得たので報告する。 


\section{○赤井亮太、藤内 謙光 \\ (大阪大学大学院工学研究科)}

機能性有機分子を用いた光電子デバイスは、塗布法 を利用した作成により材料のロスが少なくデバイスの 大面積化が可能であることから、世界中で盛んに研究 が行われている。高性能なデバイスの開発のためには、 用いる有機分子の分子構造の設計だけでなく、分子配 列の制御も非常に重要であることが知られている。分 子配列の変換手法の 1 つに有機分子にアルキル基など の置換基を直接導入する方法がある。この方法ではそ れぞれの分子の合成が必要であり、導入可能な置換基 が限定されることも多い。さらに置換基の影響で母, 骨 格の電子構造が変化し、異なる光電特性を示す可能性 もある。

そこで本研究では、有機半導体分子である [1]benzothieno[3,2-b][1] benzothiophene (BTBT) を母骨 格に持つジスルホン酸 (BTBTDS) と、光電特性には直 接的な影響を与えず、構造制御部位としてだけ働くア ルキルアミンから成る有機塩を用いて結晶中での分子 配列と光電特性に関する系統的な研究を行った。
単結晶 $\mathrm{X}$ 線構造解析の結果から、より嵩高いアミン を用いると、BTBTの分子配列は同じ herringbone 構造 でも BTBTの二面角が減少し、分子配列に変化が見ら れた。さらに嵩高いアミンを用いると、slipped-stack 構造へと大きく変化した。また、BTBTの分子配列が 微細に変わることで、隣接分子同士の相互作用が変化 し、異なる発光成分を持つ蛍光を示した。さらに結晶 構造を元にした ADF 計算結果から、分子配列の変化に 応じて、キャリアの移動度と異方性が大きく変化して いることが分かった。

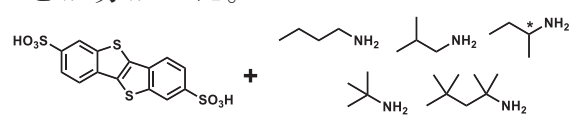

Scheme 1. BTBTDS とアルキルアミンから成る有機塩

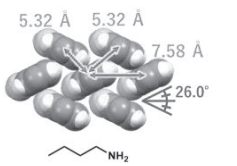

Figure 1. BTBT 骨格の分子配列変化

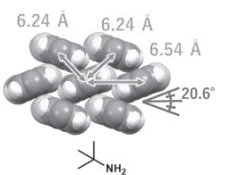

列変化

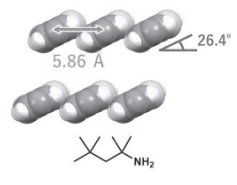

$X_{\mathrm{NH}_{2}}$

\section{PB-I-22１, 2-ビス(2,5-ジメチル-3-チェニル)ペルフルオロシクロペンテン の気相結晶成長に及ぼす基板表面の濡れ性の効果}

○磯辺 茉実、北川大地、小畠 誠也 (大阪市立大学大学院工学研究科)

\begin{abstract}
フォトクロミックジアリ ールエテンを用いて、フォト メカニカル結晶を作製する
\end{abstract} 際、結晶の形態、サイズ、厚

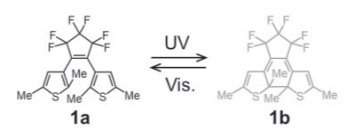

Fig. 1 Photochromism of $\mathbf{1 a}$. みを制御することは重要である。我々は、異なる濡れ性 のガラス基板を用いて、1,2-ビス(2,5-ジメチル-3-チエニ ル)ペルフルオロシクロペンテン（1a）を昇華させること で、同一の結晶構造をもつが、結晶成長方向の異なる 2 種の形態の棒状結晶を、水冷した基板表面から垂直下方 に高密度に成長させることに成功した。そこで、結晶成 長方向の違いが生じる原因を見出すため、その気相結晶 成長における機構の詳細を明らかにすることにした。

まず、結晶成長初期のガラス基板と $1 \mathrm{a}$ との関係を明 らかにするために、XRD 測定を行うと、昇華開始初期に 親水性および疎水性基板表面に吸着した薄膜表面の面 指数はそれぞれ (011) と（011) であり、その後、結晶成
長が始まると、親水性基板表面では (011) 回折ピーク、 疎水性基板表面では (011) 回折ピークの大きな増強が 確認された。これより、昇華開始直後、親水性基板表面 に対しては (011) が付着して、(011) を表面とする薄膜 が形成され、その薄膜表面から (011) を断面とする中空 結晶がへテロ接合を介して結晶成長する一方、疎水性基 板表面に対しては (011) が付着して、(011) を表面とす る薄膜が形成 され、その薄膜 表面から (011) を断面とする 羽状結晶がへ テロ接合を介 して結晶成長 することが明 らかとなった。
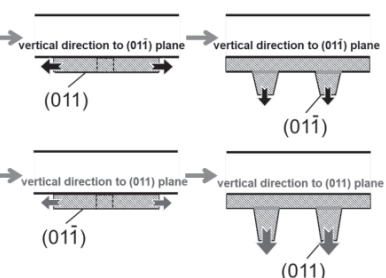
(011)

Fig. 2 Crystal growth mechanism of the thin film (a) the hydrophilic and (b) hydrophobic surfaces. Black and blue arrows indicate the vertical direction to (011) and (011), respectively. Red lines show heterojunction interfaces between $(011)$ and $(01 \overline{1})$ and rod-like crystals of $\mathbf{1}$ a on glass substrates with 
イオン液体はカチオンとアニオンから形成される常 温・常圧下で液体の溶融塩である。アニオンに鉄元素 を含み、液体と磁性の性質を持つ磁性イオン液体が Hayashi らによって合成された[1]。最近我々は、アニ オンに着目し、イミダゾリウム系 $\left[\mathrm{C}_{4} \mathrm{mim}\right]^{+}$カチオンと $\left[\mathrm{FeCl}_{4}\right]^{-}$アニオンで構成される $\left[\mathrm{C}_{4} \mathrm{mim}\right]\left[\mathrm{FeCl}_{4}\right]$ に臭素を 置換した $\left[\mathrm{C}_{4} \mathrm{mim}\right]\left[\mathrm{FeCl}_{4-x} \mathrm{Br}_{x}\right](x=0 \sim 4)$ を合成し、結晶 化および磁気特性が臭素置換量に依存することを見出 した[2]。

本研究ではアニオンにマンガンを含むイミダゾリ ウム系 $[\mathrm{EIm}]_{2}\left[\mathrm{MnCl}_{4-x} \mathrm{Br}_{x}\right](x=0 \sim 4)$ を合成し、結晶構造 および磁気・発光特性ついて調べた。単結晶 $\mathrm{X}$ 線回折 とSHELXL を用いた構造精密化から、[EIm $]_{2}\left[\mathrm{MnCl}_{4}\right]$ の結晶構造は Monoclinic, $P 22_{1} / c, a=13.699(2) \AA, b=$ 8.071(1) $\AA, c=17.080(3) \AA, \beta=92.804(7) \circ$ であることを 明らかにした（図 1)。蛍光分光光度計を用いた励起 ・ 発光スペクトルの測定から、波長 $358 \mathrm{~nm}$ の光で励起
したときに、523 nmにピーク波長を持つ緑色の発光を 示すことが分かった。当日は、段階的に臭素を置換し た $[\mathrm{EIm}]_{2}\left[\mathrm{MnCl}_{4-x} \mathrm{Br}_{x}\right]$ におりる実験結果の詳細を報告し、 発光・磁気特性における臭素置換効果について議論す る。
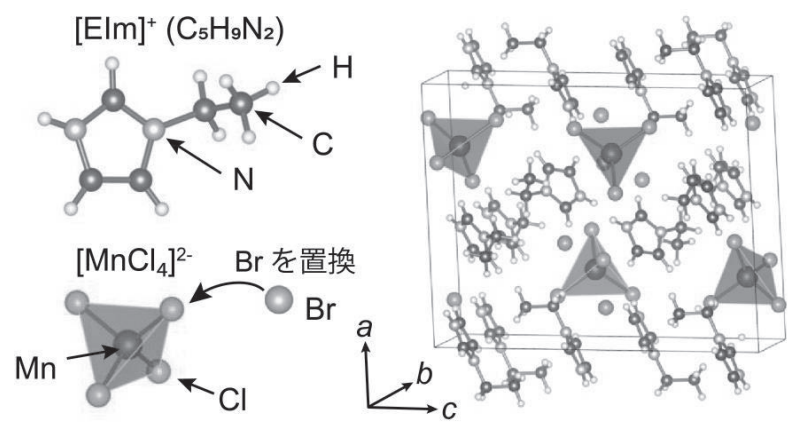

図 1. $[\mathrm{EIm}]_{2}\left[\mathrm{MnCl}_{4}\right]$ の結晶構造

[1] S. Hayashi and H.-o. Hamaguchi, Chem. Lett. 331590 (2004).

[2] H. Abe et al., Chem. Phys. Lett. 748137389 (2020).

\section{PB-I-24 エチニルアントラセン骨格を持つピリジン誘導体の 結晶構造と分光学的性質 \\ $\bigcirc$ 一杉 礼央、堀顕子 \\ (芝浦工大院理工)}

生体組織への光透過性が期待できる近赤外領域での 発光性材料 1) や発光波長を可逆的に変換できる光学 材料 2) の開発には、 $\pi$ 共役系の拡張が効果的である。 その中でも $\pi$ 平面を有するビピリジン誘導体はプロ卜 ンおよび金属イオン受容体として働くことから興味が 持たれる。これまでにエチニルアントラセンを有する 化合物 1 に着目し、錯形成反応や発光挙動を調べてき た。本研究では、2,2’-ビピリジンを導入した化合物 2 及び 3 (図 1) の結晶構造と分光学的性質を明らかにす ることを計画した。

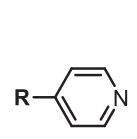

1
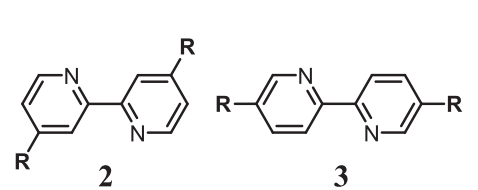

$\mathbf{R}$

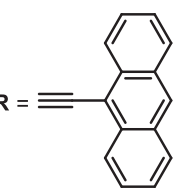

図 1 エチニルアントラセンを導入したピリジン誘導体

化合物 1 及び 2 の単結晶化にはへキサフルオロベン ゼン $\mathrm{C}_{6} \mathrm{~F}_{6}$ を少量加えることが有効であり、それぞれの
$\mathrm{CHCl}_{3}-\mathrm{C}_{6} \mathrm{~F}_{6}$ 混合溶液から自然濃縮することで単結晶 $\mathbf{1} \cdot \mathrm{C}_{6} \mathrm{~F}_{6} 、 2 \cdot 3 \mathrm{C}_{6} \mathrm{~F}_{6}$ 及び 3 を得た。単結晶 $\mathrm{X}$ 線構造解析か ら 2・3 $\mathrm{C}_{6} \mathrm{~F}_{6}$ の結晶化の駆動力は $\pi$-hole $\cdots \pi$ 相互作用3)で あることがわかった。各結晶における詳細な分子間相 互作用は Hirshfeld 表面分析及び DFT 計算より調べた。
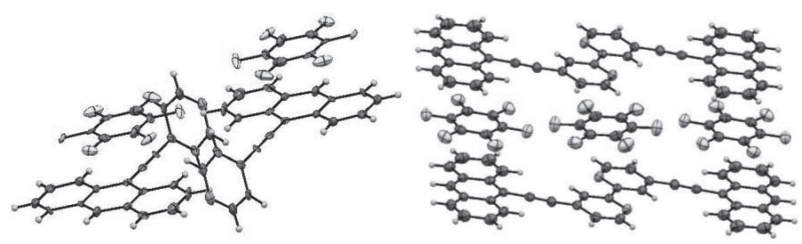

図 2 単結晶 $1 \cdot \mathrm{C}_{6} \mathrm{~F}_{6}$ と $2 \cdot 3 \mathrm{C}_{6} \mathrm{~F}_{6}$ の結晶構造

また化合物 1-3 の $\mathrm{CHCl}_{3}$ 溶液における発光極大波長 は 440、446及び $469 \mathrm{~nm}$ であり、各々 $\Phi=39$ 、62 及び $67 \%$ と高い発光量子収率を示すことがわかった。

1）上村真生，曾我公平，ぶんせき，2019，3，114-117；2）T. Seki，Y. Takamatsu, H. Ito, J. Am. Chem. Soc., 2016, 138, 6252-6260;3) X. Pang, H. Wang, W. Wang, W. J. Jin, Cryst. Growth Des., 2015, 15, 4938-4945. 